\title{
Role of Cell Cycle Regulatory Proteins in Cerebellar Granule Neuron Apoptosis
}

\author{
Jaya Padmanabhan, David S. Park, Lloyd A. Greene, and Michael L. Shelanski \\ Department of Pathology and Center for Neurobiology and Behavior, Taub Center for Alzheimer's Disease Research, \\ College of Physicians and Surgeons, Columbia University, New York, New York 10032
}

Cerebellar granule neurons (CGNs) undergo apoptosis when deprived of depolarizing concentrations of $\mathrm{KCl}$, but the underlying molecular mechanisms are not yet clear. Although caspases have been postulated to be involved in CGN cell death, inhibitors of caspases failed to prevent apoptosis under our culture conditions, suggesting an involvement of other molecules and pathways. We find that inhibitors of cyclindependent kinases-flavopiridol, olomoucine, and roscovitine-protect CGNs from $\mathrm{KCl}$ withdrawal-induced apoptosis, suggesting that cell cycle components play a significant role in the death of these neurons. Analysis of the different cell cycle regulatory elements in this model revealed that apoptosis is preceded by an increase in the level of cyclin $E$ protein, with elevated nuclear levels of cyclin D1 and with enhanced activity of the cyclin D1- and E- associated kinases. In addition, there was a significant decrease in the level of the cyclin-dependent kinase (cdk) inhibitor p27. In agreement with these changes, analysis of a major substrate of cyclin-activated cdks, retinoblastoma protein $(\mathrm{Rb})$, showed an increase in the level of phosphorylated forms within $1 \mathrm{hr}$ of $\mathrm{KCl}$ withdrawal. Moreover, the overall levels of $\mathrm{Rb}$ protein were significantly reduced within 6-12 hr of $\mathrm{KCl}$ withdrawal and did so by a caspaseindependent mechanism. All of these responses were blocked by cdk inhibitors. These findings indicate that cdks act at an early step in the pathway by which $\mathrm{KCl}$ withdrawal induces apoptotic death of cerebellar granule cells and suggest that additional elements of the cell cycle machinery participate in this mechanism.

Key words: neurons; apoptosis; cell cycle; cyclins; cdk; $R b ; C K I$
In the process of brain development an excess of neuroblasts is generated, and those that fail to reach appropriate targets at the right developmental stage are eliminated by the process of programmed cell death or apoptosis. Nowhere in the brain is this process more dramatic than in the cerebellum where there is a massive postnatal migration of neuroblasts from the external to the internal granule cell layers (Williams and Herrup, 1988; Rakic, 1998). The large number of cerebellar granule cell neuroblasts and their postnatal migration and synaptogenesis make them useful for the study of factors affecting cell survival and death both before and after migration.

Cerebellar granule neuroblasts (CGNs) cultured in vitro in the presence of serum and depolarizing concentrations of $\mathrm{KCl}(25$ $\mathrm{mm}$ ) cease division and develop a mature neuronal phenotype (Gallo et al., 1987). When extracellular $\mathrm{KCl}$ concentrations are reduced to $5 \mathrm{~mm}$, the cells become apoptotic (D'Mello et al., 1993; Yan et al., 1994; Galli et al., 1995; Schulz et al., 1996). Apoptosis can be inhibited by insulin-like growth factor-1 (IGF-1), forskolin, and inhibitors of macromolecular synthesis (D'Mello et al., 1993; Galli et al., 1995; Miller and Johnson, 1996; Schulz et al., 1996).

\footnotetext{
Received April 16, 1999; revised July 21, 1999; accepted July 30, 1999.

This work has been supported by Javits Neuroscience Awards NS-15076 and 16036 from the National Institute of Neurological Disorders and Stroke (M.L.S. and L.A.G.) and by the Blanchette Rockefeller Foundation (L.A.G.). D.S.P. is a Glaxo Wellcome Fellow.

Correspondence should be addressed to Dr. Michael L. Shelanski, Department of Pathology and Center for Neurobiology and Behavior, Taub Center for Alzheimer's Disease Research, College of Physicians and Surgeons, Columbia University, 630 West 168th Street, New York, NY 10032.

Dr. Park's present address: Neuroscience Research Institute, University of Ottawa, 451 Smith Road, Ottawa, Ontario, KIH8M5, Canada.

Copyright (C) 1999 Society for Neuroscience $0270-6474 / 99 / 198747-10 \$ 05.00 / 0$
}

The rescue by transcriptional inhibitors suggests that apoptosis in these cells depends on activation of one or more transcriptional programs and raises the question of whether this program is related to activation of components of the cell cycle machinery (Ferrari and Greene, 1996). Cell cycle regulatory proteins have been implicated previously in neuronal cell death (Park et al., 1997a). In sympathetic neurons, trophic factor withdrawalinduced death is associated with an increase in the level of cyclin D1 (Freeman et al., 1994), and overexpression of cyclin D1 in N1E-115 neuroblastoma cells induces cell death (Kranenburg et al., 1996). Moreover, chemical inhibitors of cyclin-dependent kinases (cdks) and dominant-negative forms of cdk 4 and 6 promote survival of NGF-deprived sympathetic neurons (Park et al., 1997b).

To examine whether cell cycle regulatory proteins play a role in $\mathrm{KCl}$ withdrawal-induced apoptosis of cerebellar granule neurons, we initially assessed whether the cdk inhibitors flavopiridol, olomoucine, or roscovitine could affect CGN survival in this model. Flavopiridol, a flavonoid derivative, inhibits cdk 1, 2, and 4 activities (Losievitz et al., 1994; Filgueira de Azevedo et al., 1996); olomoucine and roscovitine are purine derivatives that have been reported to inhibit cdk 1, 2, and 5 as well as early response kinase 1 and/or MAP kinase activities (Vesley et al., 1994; Meijer et al., 1997). These compounds block neuronal death evoked by trophic factor deprivation and DNA damage (Park et al., 1996, 1998a). Each of them blocks apoptosis in CGN induced by $\mathrm{KCl}$ withdrawal. We further studied the role of additional cell cycle regulatory components in CGN apoptosis, focusing our attention on the molecules involved in the $\mathrm{G} 0 \rightarrow \mathrm{G} 1 \rightarrow \mathrm{S}$ transition. The results presented below indicate roles of multiple cell cycle proteins in the induction of apoptosis in this system. 


\section{MATERIALS AND METHODS}

Materials. The peptide substrate DEVD-7-amino-4-trifluoromethyl coumarin (DEVD-AFC) and the caspase inhibitors DEVDfluoromethylketone (DEVD-FMK) and boc-aspartyl fluoromethylketone (BAF) were purchased from Enzyme Systems Products (Livermore, CA). Cell culture reagents were purchased from Life Technologies (Gaithersburg, MD). Poly-D-lysine, Percoll, and all other chemicals unless otherwise mentioned were purchased from Sigma (St. Louis, MO). Antibodies to cyclin D1, cyclin E, p27, p107, and p130 as well as the glutathione $S$-transferase (GST)-retinoblastoma protein $(\mathrm{Rb})$ substrate were purchased from Santa Cruz Biotechnology (Santa Cruz, CA); anti-Rb antibody was from Calbiochem (San Diego, CA). Phospho-Rb antibody specific for the Ser ${ }^{795}$ epitope was from New England Biolabs (Beverly, MA). Olomoucine and roscovitine were purchased from Alexis (San Diego, CA), and flavopiridol was a generous gift from Dr. Peter J. Worland (National Cancer Institute).

Cell culture. Primary cultures of cerebellar granule neurons were prepared from 8-d-old Sprague Dawley rats. The cerebella were removed, meninges were stripped, and the tissue was trypsinized and treated with DNase as reported previously (Baorto et al., 1992). The resulting cell suspension was layered on top of a step gradient, which consisted of 60 and $35 \%$ Percoll, and spun at $3000 \mathrm{rpm}(800 \times g)$ for 10 min. The cells at the interface, mainly cerebellar granule cells, were collected (Hatten, 1985). The cells were washed with cold PBS and suspended in $\mathrm{BME}$ with $10 \%$ serum and $25 \mathrm{mM} \mathrm{KCl}$ in the presence of $2 \mathrm{~mm}$ glutamine. Cells were plated into 24 well or $60 \mathrm{~mm}$ tissue culture dishes coated with $500 \mu \mathrm{g} / \mathrm{ml}$ poly-D-lysine at a cell density of $\sim 400,000$ cells per well or $8-10 \times 10^{6}$ cells per $60 \mathrm{~mm}$ dish. Twenty-four hours after cell plating, ara $\mathrm{C}$ was added to a final concentration of $10 \mu \mathrm{M}$ to prevent proliferation of non-neuronal cells. At the time of the experiments, $>95 \%$ of the cell population was granule cells.

Fluorometric analysis of caspase activity. Cerebellar granule cells were plated in $60 \mathrm{~mm}$ dishes at a density of $8-10 \times 10^{6}$ cells per dish, and after the indicated treatments, lysates were prepared in buffer A $(25 \mathrm{~mm}$ HEPES, pH 7.5, $42 \mathrm{~mm} \mathrm{KCl,} 5 \mathrm{~mm} \mathrm{MgCl}$, 1 mM PMSF, 5 mм EDTA, $1 \mathrm{~mm}$ EGTA, $1 \mathrm{~mm}$ DTT, $1 \mu \mathrm{g} / \mathrm{ml}$ pepstatin A, $1 \mu \mathrm{g} / \mathrm{ml}$ leupeptin, and $5 \mu \mathrm{g} / \mathrm{ml}$ aprotinin). Then, $25 \mu \mathrm{g}$ of protein was diluted to $1 \mathrm{ml}$ in buffer B (25 mM HEPES, pH 7.5, 1 mM EDTA, 0.1\% 3-[(3cholamidopropyl)dimethylammonio]-2-hydroxy-1-propanesulfonate,

$10 \%$ sucrose, and $1 \mathrm{~mm}$ DTT) (Stefanis et al., 1996). The fluorogenic substrate DEVD-AFC was added to a final concentration of $15 \mu \mathrm{M}$, and the fluorescent AFC production was measured in a Perkin-Elmer Luminescence Spectrometer LS50B (Norwalk, CT) with excitation at $400 \mathrm{~nm}$ and emission at $505 \mathrm{~nm}$. After the initial reading, samples were incubated at $37^{\circ} \mathrm{C}$, and readings were taken at the times indicated in the figure legend. Data are reported in arbitrary units and are corrected for basal levels of cleavage that occur without added protein.

Treatment of CGNs and survival assay. After 5-6 d in culture, the CGNs were washed with serum-free medium and maintained in BME with $25 \mathrm{~mm} \mathrm{KCl}$ for $24 \mathrm{hr}$ before lowering the $\mathrm{KCl}$ to $5 \mathrm{~mm}$ by replacement of the medium (this is referred to as " $\mathrm{KCl}$ deprivation" or " $\mathrm{KCl}$ withdrawal"). The ability of inhibitors of cdks to block apoptosis was assessed by their addition at the time of $\mathrm{KCl}$ deprivation. The cdk inhibitors used were olomoucine $(100-300 \mu \mathrm{M})$, roscovitine $(10-100$ $\mu \mathrm{M})$, and flavopiridol $(0.5$ and $1 \mu \mathrm{M})$ dissolved in DMSO. The caspase inhibitors included DEVD-FMK $(10-100 \mu \mathrm{M})$ and BAF $(10-50 \mu \mathrm{M})$ that were also dissolved in DMSO. Survival was assessed at various times after $\mathrm{KCl}$ deprivation using the cell lysis and nuclear-counting assay described previously (Rukenstein et al., 1991) and was confirmed by the MTT assay (Mosmann, 1983). Cell survival is expressed as a percentage of the cells present in $25 \mathrm{~mm} \mathrm{KCl}$ control cultures at each time point by counting the intact number of nuclei. This was confirmed by terminal deoxynucleotidyl transferase-mediated biotin-dUTP nick-end labeling (TUNEL) assay using the Boehringer Mannheim cell death detection kit according to the manufacturer's protocol. The nuclei of the cells were counterstained by incubating for $30 \mathrm{~min}$ at $4^{\circ} \mathrm{C}$ with Hoechst dye 33342 $(1 \mu \mathrm{g} / \mathrm{ml})$ after the last wash after TUNEL staining. The cells were washed again with PBS and analyzed under the fluorescent microscope.

Western blot, immunoprecipitation, and kinase assays. For these studies, CGNs were plated in $60 \mathrm{~mm}$ tissue culture dishes at a density of $8-10 \times$ $10^{6}$ cells per dish and subjected to different treatments in BME with low $\mathrm{KCl}$. The time course of cell death as well as the morphology of the cells in these dishes was similar to that observed in cells plated in 24 well plates. All biochemical analyses used cell extracts made from $60 \mathrm{~mm}$ dishes. At the indicated times, cells were washed with cold PBS, and extracts were made in lysis buffer containing 50 mM HEPES, $\mathrm{pH} 7.5,150$ mM NaCl, 1 mm EDTA, 2.5 mm EGTA, 0.1\% Tween 20, $10 \%$ glycerol, $1 \mathrm{~mm}$ DTT, $0.1 \mathrm{~mm}$ PMSF, $10 \mathrm{~mm} \beta$-glycerophosphate, $0.1 \mathrm{~mm}$ orthovanadate, $1 \mathrm{~mm} \mathrm{NaF}, 10 \mu \mathrm{g} / \mathrm{ml}$ leupeptin, and $1 \mu \mathrm{g} / \mathrm{ml}$ aprotinin (buffer $\mathrm{C}$ ). After extraction with buffer $\mathrm{C}$, the insoluble proteins in the pellet were solubilized by boiling with sample buffer. For Western blot analysis, equal amounts of proteins from the soluble lysate as well as the sample buffer-solubilized pellet $(20-30 \mu \mathrm{g})$ were resolved by PAGE and transferred to nitrocellulose membrane. Equal protein loading was verified by Ponseau S staining of the blots. Among the proteins we analyzed, only cyclin D1 was detected in the insoluble as well as the soluble fraction. All others were present only in the soluble fraction, and hence only data from the soluble fraction are shown. The membranes were incubated with 5\% nonfat milk in PBS for $2 \mathrm{hr}$ at room temperature to inhibit nonspecific binding. The blots were incubated overnight at $4^{\circ} \mathrm{C}$ with primary antibodies $(1 \mu \mathrm{g} / \mathrm{ml}$ unless otherwise specified) diluted in $3 \%$ BSA and PBS. Blots were washed with PBS and Tween-20 and incubated with goat anti-rabbit or goat anti-mouse peroxidaseconjugated secondary antibodies (Amersham, Arlington Heights, IL) at 1:1000 dilution for detection using the Pierce Super Signal ECL kit (Rockford, IL).

For the immunoprecipitation of cyclin D1- and cyclin E-associated kinases, $200 \mu \mathrm{g}$ of the cell lysates was incubated with monoclonal or polyclonal antibodies $(2 \mu \mathrm{g})$ to cyclin D1 or cyclin E, respectively, for 2 $\mathrm{hr}$ at $4^{\circ} \mathrm{C}$. The immune complexes were collected by incubating with protein A-Sepharose in the case of polyclonal antibodies or protein G-Sepharose in the case of monoclonal antibodies for a period of $1 \mathrm{hr}$ at $4^{\circ} \mathrm{C}$. The beads were washed four times using the lysis buffer and three times using kinase assay buffer (50 mM HEPES, pH 7.5, $10 \mathrm{mM} \mathrm{MgCl}_{2}$, and $1 \mathrm{~mm}$ DTT) before performing the kinase assay. Kinase reactions were performed using $20 \mu \mathrm{Ci}$ of $\left[\gamma^{-32} \mathrm{P}\right] \mathrm{ATP}$ and kinase substrate (GST$\mathrm{Rb})$ at $30^{\circ} \mathrm{C}$ for $20 \mathrm{~min}$. The concentration of substrate used in the kinase assay was $20 \mu \mathrm{g} / \mathrm{ml}$ GST-Rb. The reactions were stopped by adding $2 \times$ Laemmli sample buffer (Laemmli, 1970) and boiling the samples. Phosphorylated GST-Rb was resolved by $8 \%$ SDS-PAGE. After electrophoresis, gels were dried and exposed to Kodak MR film. For quantitative analysis, the exposed film was scanned with Adobe PhotoShop, and the intensity was measured with NIH Image 1.62.

Immunofluorescence. Cells grown in eight-chamber slides were washed with PBS and fixed for $5 \mathrm{~min}$ in methanol at $-20^{\circ} \mathrm{C}$. Fixed cells were incubated for 30 min with $10 \%$ normal goat serum in PBS to inhibit nonspecific binding before incubation with monoclonal cyclin D1 antibodies $(10 \mu \mathrm{g} / \mathrm{ml})$ for $1 \mathrm{hr}$ at room temperature. The cells were then thoroughly washed with PBS and incubated with fluorescein isothiocyanate (FITC)-conjugated donkey anti-mouse IgG (1:100 dilution in PBS containing $10 \%$ normal goat serum; Pierce) for $1 \mathrm{hr}$ at room temperature in the dark. To detect any nonspecific binding, a control was performed by incubating the cells with secondary antibody alone. After further washes the wells and gasket were removed from the slides and mounted with aqua mount (Lerner Laboratories, Pittsburgh, PA). Fluorescence was visualized under a Zeiss confocal microscope using a $100 \times$ objective.

\section{RESULTS \\ Cyclin-dependent kinase inhibitors rescue cerebellar granule neurons from apoptosis induced by KCl withdrawal}

Lowering the extracellular concentration of $\mathrm{KCl}$ from 25 to $5 \mathrm{~mm}$ induces death of cultured cerebellar granule cells (D'Mello et al., 1993; Yan et al., 1994; Galli et al., 1995). We observed 25-30\% cell death within $24 \mathrm{hr}$ and 40-60\% cell death within $48 \mathrm{hr}$ of lowering $\mathrm{KCl}$ levels. We did not observe any significant changes within $6 \mathrm{hr}$ after $\mathrm{KCl}$ withdrawal, although by $12 \mathrm{hr}$ some cell shrinkage was observed. Previous studies from our laboratories and others have suggested that aberrant activation of cell cycle molecules can play a role in the induction of apoptosis in postmitotic neurons and that cdk inhibitors block apoptosis because of trophic factor withdrawal and DNA damage (Park et al., 1996, 1997a,b, 1998a,b). To assess whether similar mechanisms are involved in death induced by $\mathrm{KCl}$ withdrawal from CGNs, we tested the ability of three cdk inhibitors, olomoucine (100-300 


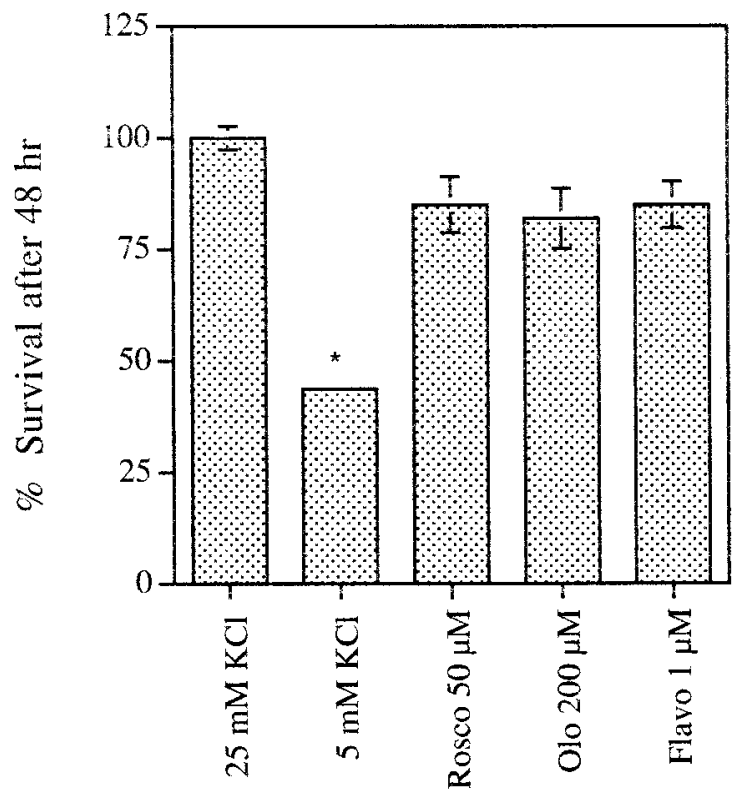

${ }^{\star} P$ value $=0.0022$

Figure 1. Cdk inhibitors protect cerebellar granule neurons from apoptosis induced by $\mathrm{KCl}$ withdrawal. Cerebellar granule neurons were treated with $50 \mu \mathrm{M}$ roscovitine (Rosco), $200 \mu \mathrm{M}$ olomoucine (Olo), or 1 $\mu \mathrm{M}$ flavopiridol (Flavo) under low $\mathrm{KCl}$ conditions, and cell survival was assessed after $48 \mathrm{hr}$ by counting the intact nuclei after cell lysis. The values are given as the percent of live cells compared with the numbers in control cultures containing $25 \mathrm{~mm} \mathrm{KCl}$. The results are presented as the mean value \pm SEM from three independent experiments done in triplicate. Statistical analysis was performed using ANOVA, and $p$ values are determined by paired $t$ test. The group that differs is indicated by the *, and the $p$ value is given at the bottom. The vehicle (DMSO) by itself did not have any effect on the cells (data not shown).

$\mu \mathrm{M})$, flavopiridol $(0.5$ and $1.0 \mu \mathrm{M})$, and roscovitine $(10-100 \mu \mathrm{M})$, to block cell death in this paradigm. All three inhibitors protected against $\mathrm{KCl}$ deprivation-induced cell death in a concentrationdependent manner. Maximum protection, 85-90\%, as assessed by counting the intact nuclei, was obtained with flavopiridol at 1 $\mu \mathrm{M}$, olomoucine at $200 \mu \mathrm{M}$, and roscovitine at $50 \mu \mathrm{M}$ after $48 \mathrm{hr}$ of $\mathrm{KCl}$ withdrawal (Fig. 1). At much lower concentrations these agents were ineffective, and at higher concentrations they were toxic (data not shown). Comparable levels of rescue were detected by counts of intact nuclei and by assessment of MTT activity (data not shown). Costaining with TUNEL and Hoechst dye 33342 showed that $\mathrm{KCl}$ withdrawal is associated with a significant increase in the number of TUNEL-positive cells with condensed nuclei. In the presence of flavopiridol, only the rare cell was TUNEL positive, and the nuclei were identical to those in controls (data not shown). The morphology of the neurons rescued by the cdk inhibitors was similar to that of the control neurons receiving depolarizing concentrations of $\mathrm{KCl}$ (Fig. 2).

Because caspases have been implicated in many models of neuronal apoptosis, we examined their role in this model of cell death. Extracts were made from $\mathrm{CGNs}$ after $\mathrm{KCl}$ deprivation for 6 and $24 \mathrm{hr}$, and the ability of the extracts to cleave the fluorogenic caspase substrates DEVD-AFC and YVAD-AFC was assessed. $\mathrm{KCl}$ withdrawal was associated with an increase in DEVD-AFC-cleaving activity (Fig. $3 B$ ) but not in YVAD cleavage (data not shown). In contrast, extracts from KCl-deprived
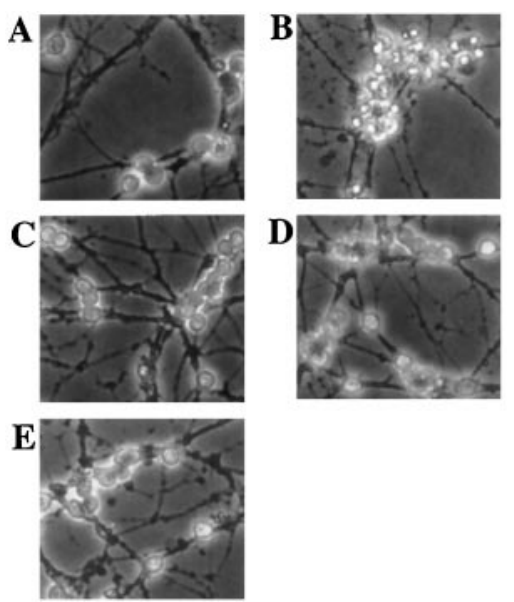

Figure 2. Morphology of cerebellar granule cells protected by cdk inhibitors. CGNs were photographed under phase optics $48 \mathrm{hr}$ after withdrawal of $\mathrm{KCl}$ in the presence or absence of the cdk inhibitors flavopiridol, olomoucine, or roscovitine. Cultures with $25 \mathrm{~mm} \mathrm{KCl}(A), 5 \mathrm{~mm} \mathrm{KCl}$ alone $(B)$, or with $1 \mu \mathrm{M}$ flavopiridol $(C), 200 \mu \mathrm{M}$ olomoucine $(D)$, or 50 $\mu \mathrm{M}$ roscovitine $(E)$ are shown. Magnification, $250 \times$.

cells that had been treated with flavopiridol did not show increased DEVD-cleaving activity. The increase in cleavage of DEVD-AFC was also blocked by treatment of the cells with the caspase inhibitor BAF, but neither BAF nor DEVD-FMK protected the cells from death at $48 \mathrm{hr}$ (Fig. $3 A$ ). None of the cell cycle inhibitors was able to inhibit caspase cleavage of DEVDAFC when added directly to cell extracts (Fig. 3C). These findings indicate that, in this paradigm, cdk activity lies upstream of the caspases and that, although caspases are activated in response to $\mathrm{KCl}$ withdrawal, they are not required for death.

\section{Changes in G1 cyclins are associated with the death of CGNs evoked by $\mathrm{KCl}$ deprivation}

The inhibition of cell death by olomoucine, roscovitine, and flavopiridol supports a role for cyclin-dependent kinases in $\mathrm{KCl}$ withdrawal-induced apoptosis of CGNs. Association with cyclins appears to be required for cdk activity, and cellular cdk activity is regulated in part by the level of cyclin expression (Pines, 1993). Because cyclin D1 has been implicated previously in apoptosis of certain neurons (Freeman et al., 1994; Kranenburg et al., 1996), we examined its level and distribution in our cultures. CGNs were deprived of $\mathrm{KCl}$ for different times in the presence or absence of flavopiridol, and cyclin D1 protein levels were assessed by Western immunoblot analysis of whole-cell extracts, in a "soluble" fraction obtained by extraction with buffer $\mathrm{C}$ and in an "insoluble" fraction obtained by reextraction of the residual pellet with SDS sample buffer. No reproducible changes were seen in cyclin D1 levels in the whole-cell extract. Over the time period there was a decrease of $\sim 25 \%$ in the soluble cyclin D1 levels (Fig. $4 B$ ). The most pronounced alteration was seen in the insoluble fraction. In this fraction, at $1 \mathrm{hr}$ of $\mathrm{KCl}$ deprivation there was no consistent alteration in the level of cyclin D1 although an occasional slight decrease was seen. By 6 hr after $\mathrm{KCl}$ withdrawal there was a slight increase in the level of cyclin D1 protein, and at $12 \mathrm{hr}$ there was a 2.5-fold increase. The level of cyclin D1 in the insoluble fraction continued to increase up to $24 \mathrm{hr}$ (3.5- to 4-fold) (Fig. 4A). Treatment of KCl-deprived cultures with flavopiridol protected the cells from death and blocked the increase in insoluble cyclin D1. The level of cyclin D1 in the insoluble fraction from 
A

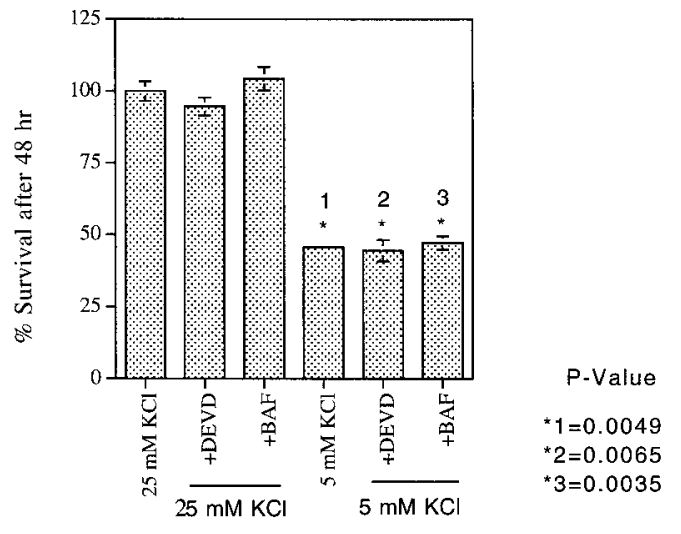

B

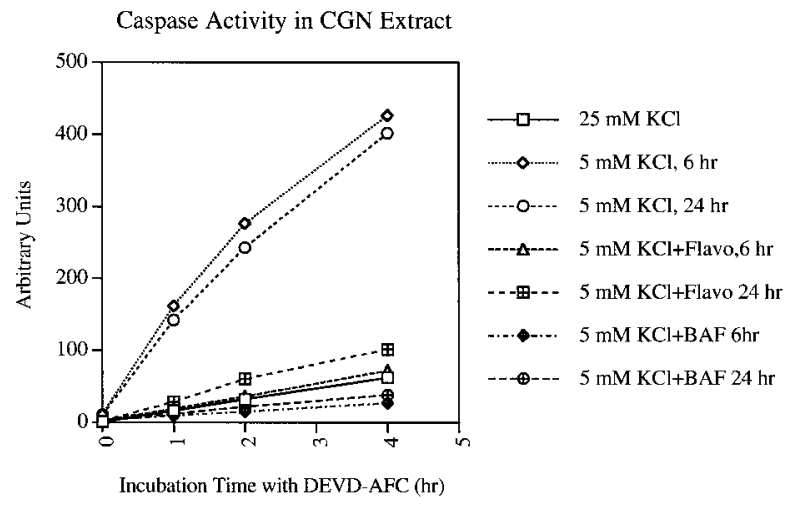

C

Caspase Activity in CGN Extract

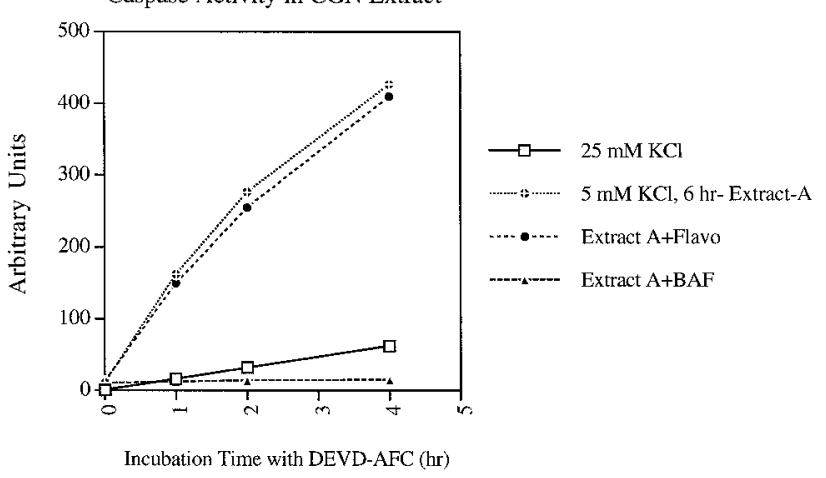

Figure 3. The caspase inhibitors DEVD-FMK and BAF do not protect cerebellar granule neurons from cell death even though $\mathrm{KCl}$ withdrawal results in elevated caspase activity. $A$, Survival. Cerebellar granule cells were treated with $50 \mu \mathrm{M}$ (final concentration) DEVD-FMK or BAF in low $\mathrm{KCl}(5 \mathrm{~mm})$ - and high $\mathrm{KCl}(25 \mathrm{~mm})$-containing media. After $48 \mathrm{hr}$, cell survival was assessed as described in Materials and Methods. The values are given as the percent of live cells compared with the numbers in control cultures containing $25 \mathrm{mM} \mathrm{KCl}$. Statistical analysis was performed using ANOVA, and $p$ values are determined by paired $t$ test. Groups that differ significantly are indicated by $* 1-3$, and the $p$ values are given at the bottom. The vehicle (DMSO) by itself did not have any effect on the cells (data not shown). $B$, Caspase activity assay. Cell extracts were made from CGNs cultured in $25 \mathrm{mM} \mathrm{KCl}$, from cultures 6 and $24 \mathrm{hr}$ after $\mathrm{KCl}$ withdrawal, and from cultures maintained in $5 \mathrm{mM} \mathrm{KCl}$ plus $50 \mu \mathrm{M}$ BAF or $1 \mu \mathrm{M}$ flavopiridol for 6 and $24 \mathrm{hr}$. Extracts $(25 \mu \mathrm{g}$ of protein/sample) were assessed for cleavage of the fluorogenic substrate DEVD-AFC as flavopiridol-treated samples was lower than the basal level seen in the presence of $\mathrm{KCl}$.

To examine the distribution of cyclin D1 protein in CGNs under different experimental conditions, we cultured neurons in chamber slides and treated the neurons with or without flavopiridol or olomoucine in $5 \mathrm{~mm} \mathrm{KCl-containing} \mathrm{media} \mathrm{for} \mathrm{a} \mathrm{period} \mathrm{of}$ $24 \mathrm{hr}$. The cultures were then fixed and stained using monoclonal anti-cyclin D1 antibody and FITC-labeled goat anti-mouse antibody, and fluorescence was visualized by confocal microscopy. Cells maintained in elevated $\mathrm{KCl}$ showed an even distribution of cyclin D1 staining (Fig. 5) throughout the cytoplasm. Withdrawal of $\mathrm{KCl}$ resulted in a marked increase in nuclear cyclin D1 staining compared with that in control cells in $25 \mathrm{~mm} \mathrm{KCl}$. This increase was inhibited by flavopiridol and olomoucine. Control cells stained with secondary antibody alone appeared negative. These findings correlate well with the biochemical observations reported above and indicate that $\mathrm{KCl}$ deprivation shifts the cellular localization of cyclin D1 to the nucleus and that these alterations are blocked by cdk inhibitors.

We next examined the levels of cyclin $\mathrm{E}$ after induction of apoptosis in CGNs. Analysis of extracts from early time points (up to $5 \mathrm{hr}$ ) after $\mathrm{KCl}$ deprivation did not show any significant increase in the full-length $(52 \mathrm{kDa})$ cyclin E protein. However, after $6 \mathrm{hr}$ of $\mathrm{KCl}$ deprivation, we observed additional cyclin $\mathrm{E}$ cross-reactive bands with apparent molecular weights of 30 and 40 $\mathrm{kDa}$. The intensity of these bands increased twofold from 6 to 12 $\mathrm{hr}$ after $\mathrm{KCl}$ withdrawal, whereas they were very weak or undetectable in control cultures (Fig. 4B). Treatment of the cells with flavopiridol under low $\mathrm{KCl}$ conditions inhibited the appearance of these lower $M_{\mathrm{r}}$ bands. However, these bands were unaffected by BAF, suggesting that their formation was not the result of caspase activity (data not shown). The identity of the lower molecular weight bands is not known, but lower molecular weight cyclin E-related proteins have been detected (with both polyclonal and monoclonal cyclin $\mathrm{E}$ antibodies) in tumors where there is disregulation of cell cycle machinery (Sgambato et al., 1995; Gray-Bablin et al., 1996). These lower molecular weight proteins have also been shown to enhance cyclin E-associated kinase activity in these systems.

\section{Apoptosis in CGNs is associated with an increase in cdk activity}

The inhibition of cell death by the cdk inhibitors flavopiridol, olomoucine, and roscovitine prompted us to study the activity of cyclin-dependent kinases during CGN apoptosis. To examine this, CGNs were deprived of $\mathrm{KCl}$ for different time periods in the presence or absence of cdk inhibitors, and cell extracts were made. Cyclin D1- and E-associated kinases were immunoprecipitated using a cyclin D1 monoclonal antibody or cyclin E polyclonal antibody, respectively. An in vitro kinase assay was per-

\footnotetext{
described in Materials and Methods. The measurements were made at 0 , $1,2,3$, and $4 \mathrm{hr}$ time points after addition of DEVD-AFC. The figure is a representative of three independent experiments. $C$, Caspase activity in the extract in the presence of BAF or flavopiridol. The cell extract from $6 \mathrm{hr}$ after $\mathrm{KCl}$ withdrawal that showed the maximum caspase activity in $B$ was chosen for this experiment. BAF $(50 \mu \mathrm{M})$ or flavopiridol $(1 \mu \mathrm{M})$ was added to the cell extract before the addition of DEVD-AFC substrate, and measurements were made at $0,1,2,3$, and $4 \mathrm{hr}$ time points. Comparable results were obtained in three independent experiments.
} 


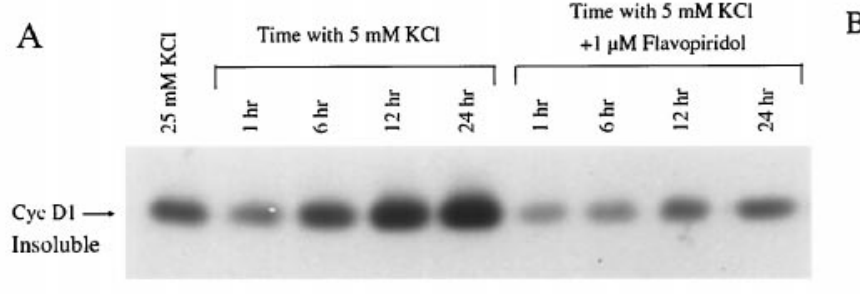

$\mathrm{C}$

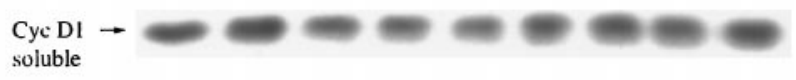

B

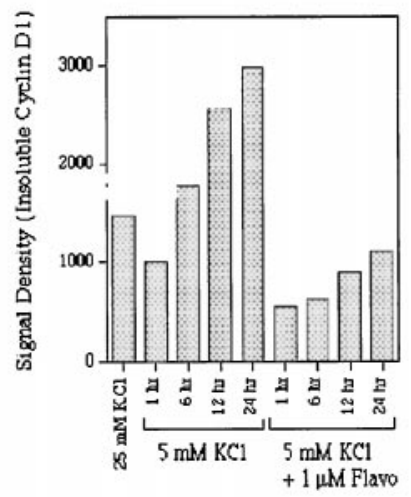

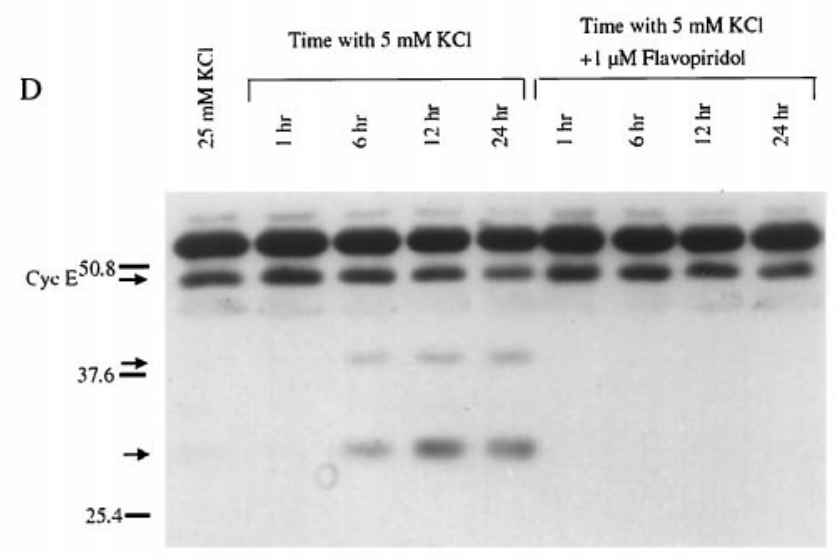

Figure 4. Effect of $\mathrm{KCl}$ withdrawal on cyclin D1 and E levels in CGNs. Cell extracts were prepared from CGNs deprived of $\mathrm{KCl}$ for 1, 6, 12 , and 24 $\mathrm{hr}$ in the presence or absence of flavopiridol as described in Materials and Methods. $A, C, D$, In the case of cyclin D1, the data from both insoluble and soluble fractions are provided. Equal amounts of protein samples were resolved by SDS-PAGE, and Western immunoblot analysis was performed using a monoclonal antibody to cyclin D1 (Cyc D1; $A$, insoluble; $C$, soluble) or a polyclonal cyclin E antiserum $(C y c E ; D)$. Note in $D$ the appearance of two cyclin E-related proteins at molecular weights around 30 and $40 \mathrm{kDa}$ (arrows). The figure in $D$ is obtained by stripping the blot shown in $C$ and reprobing with cyclin $\mathrm{E}$ antibody. Cyclin $\mathrm{E}$ was not detected in the insoluble fraction. $B$, The graphical representation of the intensity of the bands shown in $A$ is obtained by scanning and analyzing the blot using NIH Image 1.62.

formed using the immune complexes and GST-Rb as substrate. Our results show that $\mathrm{KCl}$ deprivation-induced death of CGNs is associated with an increase in cyclin D1-associated kinase activity within $4 \mathrm{hr}$ (Fig. 6A). By $8 \mathrm{hr}$ this increase is more than threefold (Fig. 6A, lane 3 from left) and was sustained at this level up to 24 hr (data not shown). The increase in activity is completely inhibited in cells treated with flavopiridol, olomoucine, or roscovitine.

Because no enhancement in cyclin E-associated kinase activity was detected at $5 \mathrm{hr}$ after $\mathrm{KCl}$ deprivation (data not shown), we examined material from earlier time points. Cyclin E-associated kinase activity was elevated within $30 \mathrm{~min}$ of $\mathrm{KCl}$ withdrawal; although activity was sustained for $1 \mathrm{hr}$, it returned to near baseline by 3 hr of deprivation (Fig. 6D). Thus, both cyclin D1and E-associated kinase activities are elevated in response to $\mathrm{KCl}$ withdrawal, but the time courses of these are distinct from one another.

\section{Decrease in the level of kinase inhibitory protein p27kip1 during CGN death}

Because pharmacological cdk inhibitors protect CGNs from apoptosis induced by $\mathrm{KCl}$ deprivation, we examined the behavior of endogenous cyclin kinase inhibitors (CKIs) in this process. Extracts were made from control and experimental CGN cultures at $1,2,3,5$, and $21 \mathrm{hr}$ after $\mathrm{KCl}$ deprivation, and the levels of $\mathrm{p} 16$, p21, and p27 CKI proteins were analyzed by Western immunoblotting. Up to $3 \mathrm{hr}$ there was no significant change in p27 levels that was followed by a decrease to $50-60 \%$ of control levels at 5 hr of $\mathrm{KCl}$ withdrawal and to $40 \%$ of control values at $21 \mathrm{hr}$ (Fig. $7 A$ ). When KCl-deprived cells were treated with flavopiridol, the decrease in p27 we observed was significantly inhibited $(80 \%$ of control value after 5 and $21 \mathrm{hr}$ ). The level of p21, in contrast, was unaffected by lowering the $\mathrm{KCl}$ concentration (Fig. 7B,C), and there was no p16 detected in the CGNs. The decrease in the level 


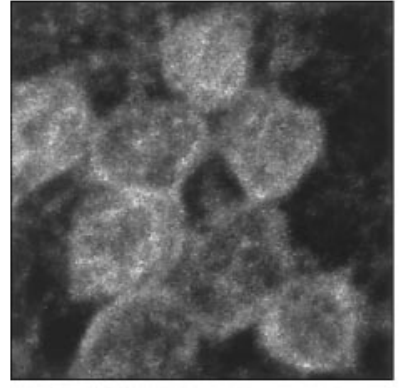

$25 \mathrm{mM} \mathrm{KCl}$

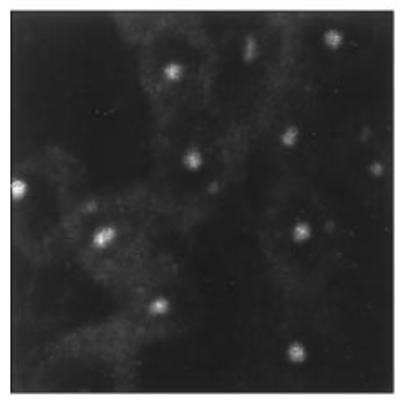

$5 \mathrm{mM} \mathrm{KCl}+$ Flavo

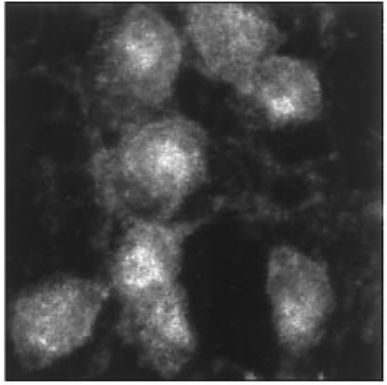

$5 \mathrm{mM} \mathrm{KCl}$

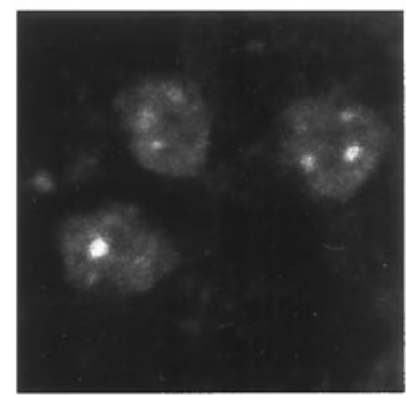

$5 \mathrm{mM} \mathrm{KCl}+$ Olo
Figure 5. $\mathrm{KCl}$ deprivation causes a change in distribution of cyclin D1 in CGNs. CGNs were deprived of $\mathrm{KCl}$ and treated with $1 \mu \mathrm{M}$ flavopiridol or $200 \mu \mathrm{M}$ olomoucine for $24 \mathrm{hr}$. The cells were fixed and stained with a monoclonal anti-cyclin D1 antibody and FITC-conjugated anti-mouse secondary antibody. Fluorescence was visualized using a confocal microscope. In the presence of cdk inhibitors, staining appears to be elevated in nucleoli. A control done by staining the cells with secondary antibody alone did not show any significant nonspecific staining (data not shown). Magnification, $500 \times$.

of $\mathrm{p} 27$ could contribute to the increase in cdk activity that occurs after $\mathrm{KCl}$ withdrawal.

\section{Rb phosphorylation and degradation during cerebellar granule cell death}

Cdks associated with cyclins D and E are known to phosphorylate $\mathrm{Rb}$ and other members of the pocket protein family, releasing and activating bound transcription factors such as E2F. The observations that $\mathrm{KCl}$ withdrawal-induced apoptosis of CGNs is associated with an increase in cyclin D1- and E-associated kinase activities suggested that there might be a consequent alteration in the phosphorylation status of Rb. To examine this, we performed Western immunoblot analysis with samples made from CGNs at various time points between 1 and $48 \mathrm{hr}$ of $\mathrm{KCl}$ deprivation. Analysis with an antibody specific to phospho-RB Ser ${ }^{795}$ revealed that the level of phosphorylated $\mathrm{Rb}$ is significantly increased ( $180 \%$ of control value) after $1 \mathrm{hr}$ of $\mathrm{KCl}$ deprivation (Fig. $8 C$ ), although the level of $\mathrm{Rb}$ protein does not change at this time (Fig. $8 B$ ). Moreover this increase in $\mathrm{Rb}$ phosphorylation was blocked by flavopiridol (Fig. 8C). Elevation of phospho-Rb levels was no longer detectable $6 \mathrm{hr}$ after $\mathrm{KCl}$ withdrawal. However, unexpectedly there was a significant loss of $\mathrm{Rb}$ protein at this time. The level of $\mathrm{Rb}$ continued to drop beyond $6 \mathrm{hr}$ of $\mathrm{KCl}$ withdrawal and reached $10-25 \%$ of control values by $24 \mathrm{hr}$. This loss of Rb was blocked by each of the three cdk inhibitors at all time points studied up to $48 \mathrm{hr}$ (Fig. 8A,B). In FAS-mediated apoptosis, loss of $\mathrm{Rb}$ appears to require caspase activation (Chen et al., 1997;
Ping Dou et al., 1997). However, in the present $\mathrm{KCl}$ withdrawal paradigm, the general caspase inhibitor BAF did not block the fall in $\mathrm{Rb}$ levels. These findings indicate that $\mathrm{KCl}$ withdrawal elicits a rapid elevation of $\mathrm{Rb}$ phosphorylation followed by caspaseindependent loss of $\mathrm{Rb}$ protein.

We also examined the levels of the Rb-related pocket proteins p107 and p130 after $\mathrm{KCl}$ withdrawal. Western immunoblotting of $\mathrm{p} 107$, unlike the case of $\mathrm{Rb}$, revealed no significant loss after $\mathrm{KCl}$ withdrawal. In contrast, it showed a slight increase in levels at 18 and $24 \mathrm{hr}$ after $\mathrm{KCl}$ withdrawal (Fig. 9). We could not unambiguously resolve the various phosphorylated forms of p107 and therefore could not assess whether $\mathrm{KCl}$ withdrawal affects the phosphorylation of this protein. The increase we observed after $\mathrm{KCl}$ withdrawal was inhibited in the presence of flavopiridol. Finally, we did not observe any significant change in the level of p130 after $\mathrm{KCl}$ withdrawal (data not shown).

\section{DISCUSSION}

There are several reports suggesting that caspases may play a role in cell death in CGNs (Schulz et al., 1996; Armstrong et al., 1997), and we were surprised that the caspase inhibitors alone were not sufficient to protect from death in our experimental system. Although death was not inhibited, the inhibitors did block the increase in caspase activity observed in association with $\mathrm{KCl}$ withdrawal. This agrees with the observations made in Bax knock-out mice (Miller et al., 1997) in which CGNs did not undergo apoptosis after $\mathrm{KCl}$ withdrawal although there was an increase in the level of caspase 3 mRNA. CGNs from wild-type mice also showed a caspase 3 mRNA increase, and caspase inhibitors were unable to protect these cells from $\mathrm{KCl}$ withdrawal-induced death. Therefore, apoptosis in these cells is caused by either a caspase that is not inhibited by any of the inhibitors tested or a caspase-independent pathway. It is also possible that the differences in results reflect the type of insult, the age of the cultures, or the culture conditions. An example of the first of these is the blockade of glutamate-mediated death in CGN by DEVD (Du et al., 1997).

The results presented here extend the number of models of neuronal cell death in which cell cycle elements appear to participate. However, it is clear that not all pathways of neuronal death rely on cell cycle molecules. For instance, we found that cdk inhibitors did not inhibit neuronal apoptosis induced by downregulation of superoxide dismutase 1 (Troy et al., 1997).

Although flavopiridol, olomoucine, and roscovitine have activities in addition to inhibition of cdks (Vesley et al., 1994; Meijer et al., 1997), we have provided evidence that the latter mechanism is the most likely means by which they promote neuronal survival (Park et al., 1996, 1997a, 1998a,b). Moreover, in the NGF deprivation and DNA damage models, in addition to these inhibitors, rescue is provided by overexpression of CKIs or of dominantnegative forms of cdk 4 and 6 (Park et al., 1997b).

In agreement with a role of cdks in the death of CGNs, we observed early increases in cyclin D- and cyclin E-associated kinase activities after withdrawal of elevated $\mathrm{KCl}$. We also found pronounced nuclear accumulation of cyclin D. A similar association of cyclin D1 with the nucleus is seen in human fibroblasts during G1 (Pagano et al., 1994), and the association is inhibited by the protein kinase inhibitor staurosporin, which also induces cell cycle arrest in early G1 (Scovassi et al., 1997). D-type cyclins along with their partners cdk 4 and/or 6 play primary roles in the transition from quiescence to $\mathrm{S}$ phase. Cyclin $\mathrm{E}$ is also required for the G1/S transition but seems to operate after cyclin D. In this 
$\mathbf{A}$
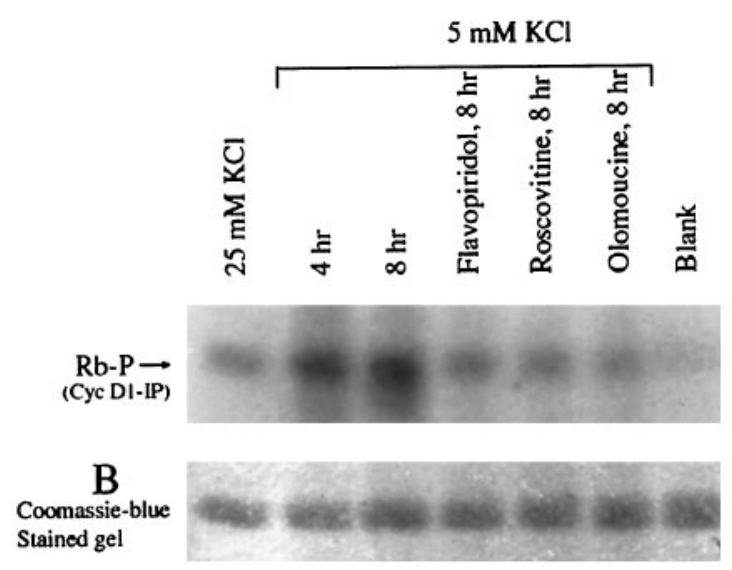

D

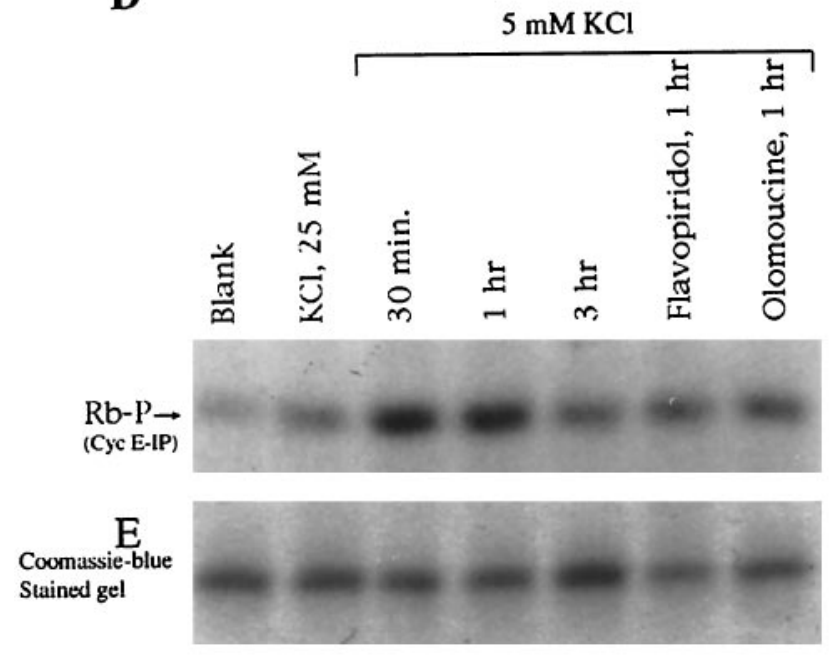

respect, it may be relevant that the cdk inhibitors we used block the G1/S transition and that pharmacological G1/S blockers protect neurons from death in several different paradigms.

Although the increase in cyclins $\mathrm{E}$ caused by $\mathrm{KCl}$ withdrawal may contribute to enhanced cdk activity, it is clear that there is considerable basal expression of both cyclin D and E in CGNs even under culture conditions that maintain survival. Thus, it may be that death can be triggered without the necessity for massive elevation of cyclin levels. This appears to contrast with the case of sympathetic neurons in which cyclin D transcripts were reported to be detectable only after NGF deprivation (Freeman et al., 1994). In the present case, the distribution rather than the absolute level of cyclin D appears to be the critical feature in the death mechanism.

In addition to cyclins, CKIs also play a major role in regulating cdk activity. These bind a wide range of cdk/cyclin complexes and suppress their activity as well as activation and, as a consequence, promote growth arrest. We observed that $\mathrm{KCl}$ withdrawal results in a significant loss of the CKI p27kip1. This effect may contribute to the activation of cdks induced by withdrawal of depolarizing levels of $\mathrm{KCl}$.
Cyclin D1 Associated Kinase Assay

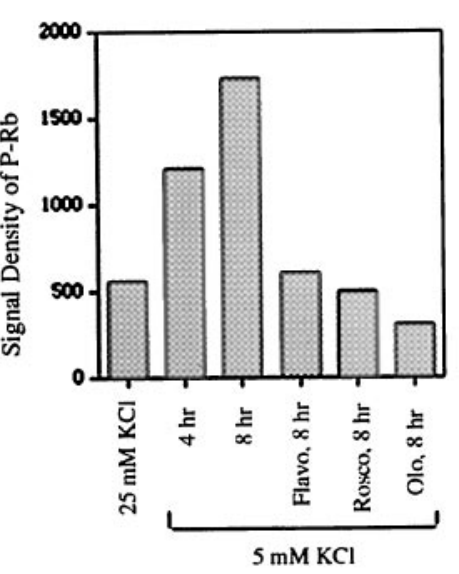

F

Cyclin E Associated Kinase Assay

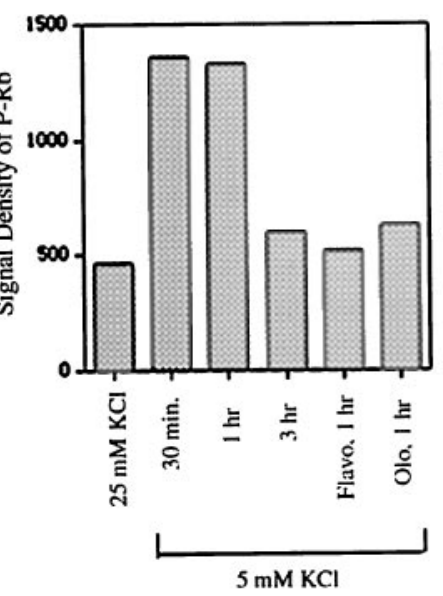

Figure 6. Cyclin-associated cdk activities increase in CGNs deprived of $\mathrm{KCl}$. $A$, Cyclin D1-associated cdk activity. Cell extracts were made from CGNs after 4 and $8 \mathrm{hr}$ of $\mathrm{KCl}$ withdrawal and from cultures in the presence of flavopiridol $(1 \mu \mathrm{M})$, olomoucine $(200 \mu \mathrm{M})$, or roscovitine $(50 \mu \mathrm{M})$ and deprived of $\mathrm{KCl}$ for $8 \mathrm{hr}$. Equal amounts of protein were used for immunoprecipitation of the cyclin D1-associated kinases using a monoclonal cyclin D1 antibody. The immune complexes were assessed for kinase activity using GST-Rb as substrate in the presence of $\left[\gamma_{-}{ }^{32} \mathrm{P}\right] \mathrm{ATP}$. The labeled $\mathrm{Rb}(R b-P)$ is resolved by SDS-PAGE and visualized by autoradiography. This figure is a representative of three independent experiments. $B$, Coomassie blue staining of the same gel shown in $A$ showing the level of substrate in each sample. $C$, Graphical representation of the intensity of the $R b-P$ bands in $A$ after subtracting the nonspecific blank signal (obtained with a sample treated similarly, except omitting the primary antibody in the immunoprecipitation). The autoradiograph was scanned and analyzed using NIH Image 1.62. $D$, Cyclin E-associated cdk activity. This experiment was performed as described in $A$ except that the times of $\mathrm{KCl}$ withdrawal were 30 min, $1 \mathrm{hr}$ ( \pm flavopiridol or olomoucine), and $3 \mathrm{hr}$ and that polyclonal cyclin $\mathrm{E}$ antiserum was used for the immunoprecipitation. $E$, Coomassie blue staining of the same gel shown in $D$ showing the level of substrate in each sample. F, Graphical representation of the intensity of the bands shown in $C$ after subtracting the intensity of the blank sample. IP, Immunoprecipitate.
Because our findings point to the activation of cdks in the response of CGNs to $\mathrm{KCl}$ withdrawal, we examined the key physiological substrate of cyclin D-cdk 4/6, the retinoblastoma protein. We found that $\mathrm{Rb}$ is rapidly phosphorylated in response to $\mathrm{KCl}$ withdrawal and that this, as well as basal phosphorylation of $\mathrm{Rb}$, is blocked by flavopiridol. These observations are consistent with the notion that the elevation of cdk activity evoked by lowering extracellular $\mathrm{KCl}$ leads to $\mathrm{Rb}$ phosphorylation.

Examination of $\mathrm{Rb}$ revealed that the levels of this protein fall significantly by $6 \mathrm{hr}$ of $\mathrm{KCl}$ withdrawal and are greatly diminished at the time apoptotic death first becomes detectable (12-24 hr). Although it is unclear whether the delayed loss of $\mathrm{Rb}$ is dependent on its phosphorylation, this possibility is supported by our observation that this process is blocked by cdk inhibitors. The time course of $\mathrm{Rb}$ disappearance does not correlate with the early appearance of cyclin E-associated kinase activity or of enhanced $\mathrm{Rb}$ phosphorylation but is temporally more closely associated with the later translocation of cyclin D and with the cyclin $\mathrm{D}$-associated kinase activity and fall in p27kip1 levels. This raises the possibility that there is a late-occurring phosphorylation of $\mathrm{Rb}$ driven by cyclin $\mathrm{D}$-associated kinase(s) and that this event 

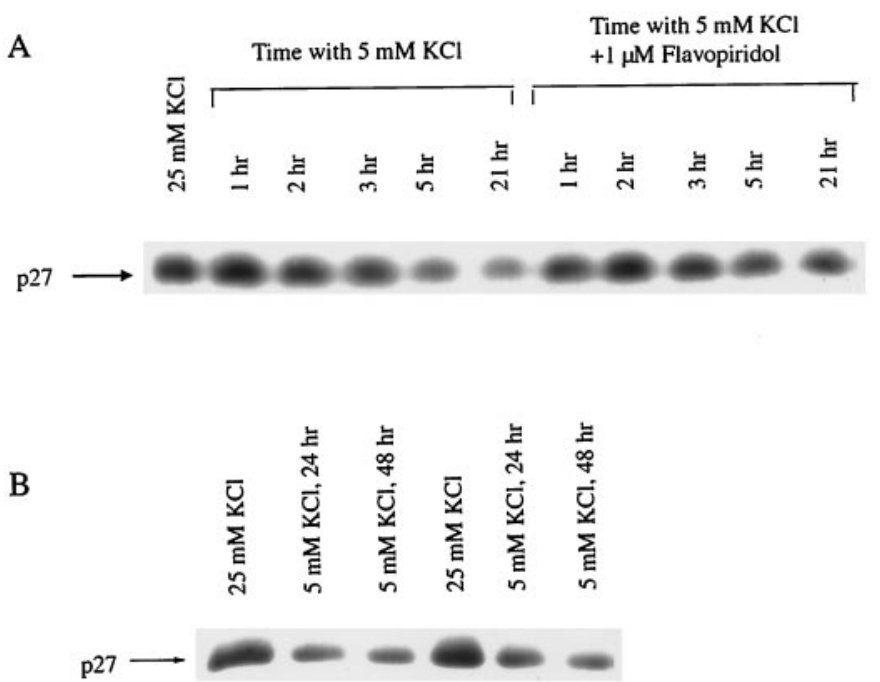

$\mathrm{C}$

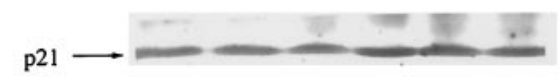

Figure 7. p27 levels fall in CGNs deprived of $\mathrm{KCl}$. A, Cell extracts were prepared from CGNs deprived of $\mathrm{KCl}$ ( \pm flavopiridol) for 1, 2, 3, 5, and $21 \mathrm{hr}$. Equal amounts of proteins were resolved by SDS-PAGE. Western immunoblot analysis was performed using a polyclonal anti-p27 antiserum. Comparable results were obtained in three independent experiments. $B$, Cell extracts prepared from CGNs deprived of $\mathrm{KCl}$ for 24 and $48 \mathrm{hr}$ were used to analyze p27 levels using polyclonal antibody to $227 . C$, The blot from $B$ was stripped and reprobed with a polyclonal p21 antibody.

leads to rapid depletion of the protein. This would explain why the phosphorylated form of the protein is difficult to detect after $6 \mathrm{hr}$ of $\mathrm{KCl}$ withdrawal. In FAS-mediated cellular apoptosis, $\mathrm{Rb}$ protein is also lost (Chen et al., 1997; Ping Dou et al., 1997). In this instance, it is a phosphorylated form of the protein that is degraded, whereas the nonphosphorylated form is relatively stable. It is significant, however, that in the latter case $\mathrm{Rb}$ was degraded by caspases, whereas in the present work the general caspase inhibitor BAF did not protect from Rb loss (or death), even though it effectively suppressed caspase activity. Thus, it seems that a mechanism other than degradation by caspases is responsible for the loss of $\mathrm{Rb}$ in $\mathrm{KCl}$-deprived CGNs.

The observation that Rb-null mice show extensive neuronal loss suggests that $\mathrm{Rb}$ is an important anti-apoptotic element in the developing brain and supports the possibility that there is a causal association between the observed loss of Rb and CGN death in culture. A major function of $\mathrm{Rb}$ is to bind and repress the transcriptional activity of E2F (Chellappan et al., 1991; Helin et al., 1992). Of direct relevance to the present studies, overexpression of free E2F triggers cell death in a variety of different systems (Wu and Levine, 1994; Kowalik et al., 1995; Adams and Kaelin, 1996; Asano et al., 1996; Field et al., 1996; Shan et al., 1996). On this basis, it may be hypothesized that the $\mathrm{KCl}$ withdrawalevoked loss of $\mathrm{Rb}$ protein in CGN leads to release of free $\mathrm{E} 2 \mathrm{~F}$ and that the latter in turn mediates death. Alternatively E2F-Rb complexes mediate gene repression, and loss of $\mathrm{Rb}$ would lead to gene derepression that might in turn play a role in the apoptotic mechanism.

It is notable that the entire set of events described here including early elevation of cyclin E-associated kinase activity and $\mathrm{Rb}$ hyperphosphorylation, cyclin D nuclear translocation, elevation
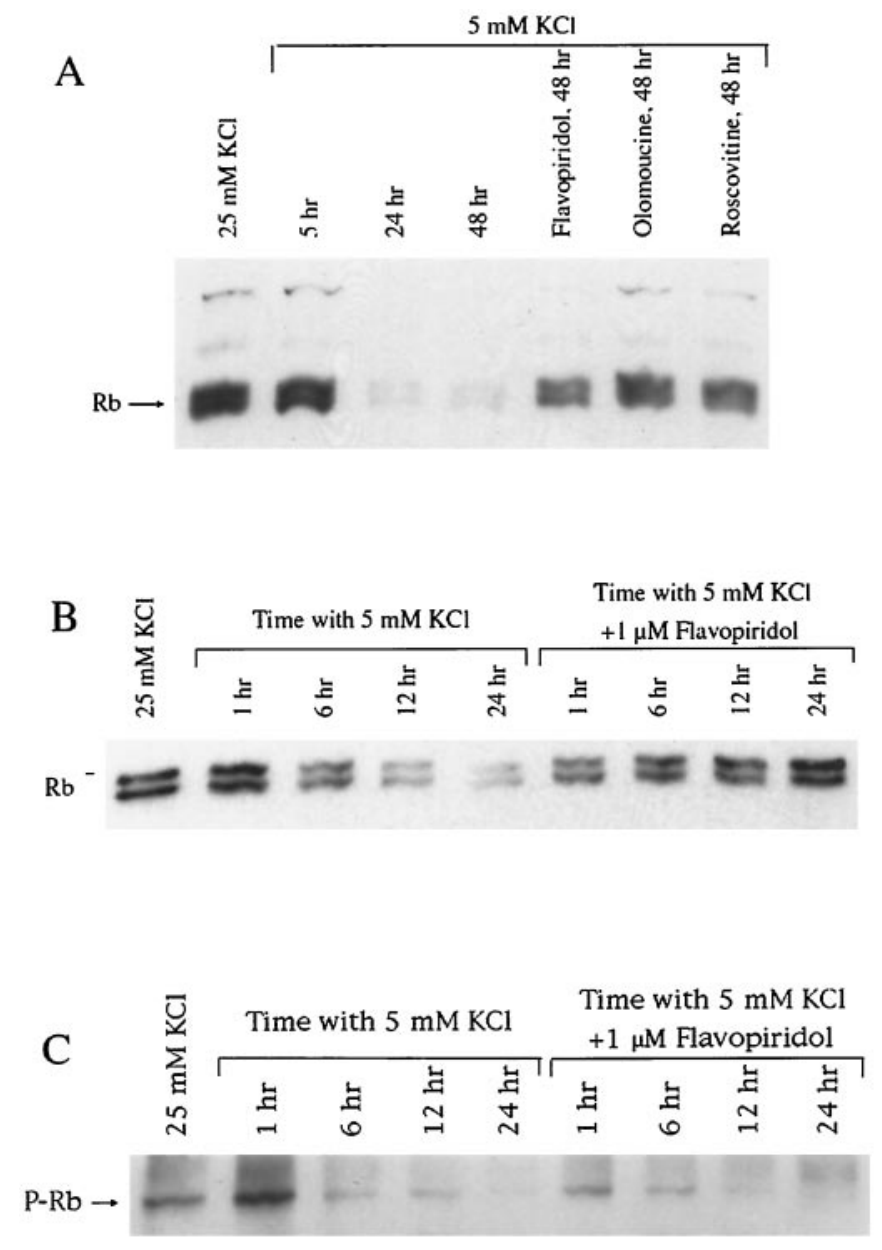

Figure 8. CGN cell death is associated with $\mathrm{Rb}$ phosphorylation followed by a significant decrease in the level of $\mathrm{Rb} . A, \mathrm{KCl}$ withdrawal is associated with a decrease in the level of $\mathrm{Rb}$. Western immunoblot analysis with a monoclonal $\mathrm{Rb}$ antibody was performed on samples (containing equal amounts of protein) made from CGNs deprived of $\mathrm{KCl}$ for 5,24 , and $48 \mathrm{hr}$ and from cells treated with flavopiridol $(1 \mu \mathrm{M})$, olomoucine $(200 \mu \mathrm{M})$, or roscovitine $(50 \mu \mathrm{M})$ under low $\mathrm{KCl}$ conditions for $48 \mathrm{hr}$. Comparable results were obtained in three independent experiments. $B$, The time course of $\mathrm{Rb}$ loss after $\mathrm{KCl}$ withdrawal is shown. Samples (containing equal amounts of protein) from cells treated with or without flavopiridol $(1 \mu \mathrm{M})$ under low $\mathrm{KCl}$ conditions for a period of 1,6 , 12 , and $24 \mathrm{hr}$ were subjected to Western immunoblot analysis using a monoclonal $\mathrm{Rb}$ antibody. $B$ is obtained by stripping the blot shown in Figure $4 C$ and reprobing with $\mathrm{Rb}$ antibody. $C$, The level of phospho- $\mathrm{Rb}$ $(P-R b)$ in CGNs switched to $5 \mathrm{~mm} \mathrm{KCl}$ is shown. The blot in $B$ is stripped, and immunoblot analysis was performed using a polyclonal antibody specific for the Ser 795 epitope of phospho-Rb. Comparable results were obtained in three independent experiments.

of cyclin D-associated kinase activity, the fall in p27kip1 levels, loss of $\mathrm{Rb}$ protein, and death itself are all blocked by each of the three cdk inhibitors we used. This indicates that these inhibitors act at a relatively early point in the apoptotic pathway.

Although these findings and past findings implicate molecules associated with proliferation in normal death, our observation should not be taken to indicate that dying neurons actually reenter a normal cell cycle. Rather, in the postmitotic neuron, such molecules may have the additional role of contributing to the apoptotic mechanism.

As noted above, pharmacological $\mathrm{Cdk}$ inhibitors as well as overexpression of CKIs or dominant-negative forms of certain 

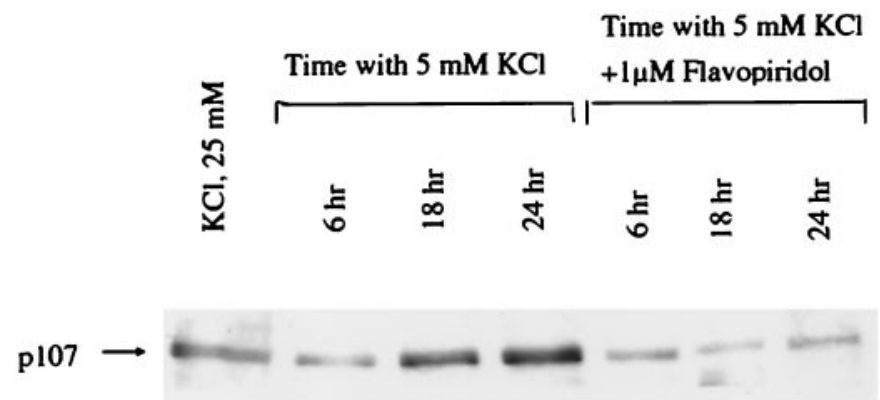

Figure 9. p107 levels in CGNs deprived of KCl. Cell extracts were prepared from CGNs deprived of $\mathrm{KCl}$ ( \pm flavopiridol) for 6,18 , and 24 hr. Equal amounts of protein were resolved by SDS-PAGE. Western immunoblot analysis was performed using a polyclonal anti-p107 antibody. Comparable results were obtained in three independent experiments.

Cdks protect cultured neurons from death evoked by DNAdamaging agents. We have recently analyzed cell cycle-related proteins in such cells (Park et al., 1998b), and it is of some interest to compare results with the present experiments. In response to the DNA-damaging agent camptothecin, cortical neurons show, as in the present case, induction of cyclin D-associated kinase activity, enhanced $\mathrm{Rb}$ phosphorylation, and delayed loss of $\mathrm{Rb}$ protein (all of which were blocked by flavopiridol). In contrast, however, p107 was also lost, and this loss, as well as loss of Rb, was blocked by the caspase inhibitor BAF (D. S. Park, J. Padmanabhan, M. L. Shelanski, and L. A. Greene, unpublished observations). These differences indicate that although there may be many elements in common in death pathways evoked in different neurons by different apoptotic stimuli, there are also significant distinctions that must be considered.

\section{REFERENCES}

Adams PD, Kaelin Jr WG (1996) The cellular effects of E2F overexpression. Curr Top Microbiol Immunol 208:79-93.

Armstrong RC, Aja TJ, Hoang KD, Gaur S, Bai X, Alnemri ES, Litwack G, Karaneswsky DS, Fritz LC, Tomaselli KJ (1997) Activation of the CED3/ICE-related protease CPP32 in cerebellar granule neurons undergoing apoptosis but not necrosis. J Neurosci 17:553-562.

Asano M, Nevins JR, Wharton RP (1996) Ectopic E2F expression induces S phase and apoptosis in Drosophila imaginal discs. Genes Dev 10:1422-1432.

Baorto D, Mellado W, Shelanski ML (1992) Astrocyte process growth induction by actin breakdown. J Cell Biol 117:357-367.

Chellappan SP, Hiebert S, Mudryj M, Horowitz JM, Nevins JR (1991) The E2F transcription factor is a cellular target for the RB protein. Cell 65:1053-1061.

Chen WD, Otterson GA, Lipkowitz S, Khleif SN, Coxon AB, Kaye FJ (1997) Apoptosis is associated with cleavage of a $5 \mathrm{kDa}$ fragment from $\mathrm{RB}$ which mimics dephosphorylation and modulates E2F binding. Oncogene 14:1243-1248.

D'Mello SR, Galli C, Ciotti T, Calissano P (1993) Induction of apoptosis in cerebellar granule neurons by low potassium: inhibition of death by insulin-growth factor 1 and cAMP. Proc Natl Acad Sci USA 90:10989-10993.

Du Y, Bales KR, Dodel RC, Hamilton-Byrd E, Horn JW, Czilli DL, Simmons LK, Ni B, Paul SM (1997) Activation of a caspase 3-related cysteine protease is required for glutamate-mediated apoptosis of cultured cerebellar granule neurons. Proc Natl Acad Sci USA 94:11657-11662.

Ferrari G, Greene LA (1996) Prevention of neuronal apoptotic death by neurotrophic agents and ganglioside GM1: insights and speculations regarding a common mechanism. Perspect Dev Neurobiol 3:93-100.
Field SJ, Tsai FY, Kuo F, Zubiaga AM, Kaelin WGJ, Livingston DM, Orkin SH, Greenberg ME (1996) E2F-1 functions in mice to promote apoptosis and suppress proliferation. Cell 85:549-561.

Filgueira de Azevedo W, Mueller-Dieckmann H-J, Schulze-Gahmen U, Worland PJ, Sausville E, Kim S-H (1996) Structural basis for specificity and potency of a flavonoid inhibitor of human cdk2, a cell cycle kinase. Proc Natl Acad Sci USA 93:2735-2740.

Freeman RS, Estus S, Johnson Jr EM (1994) Analysis of cell cyclerelated gene expression in postmitotic neurons: selective induction of cyclin D1 during programmed cell death. Neuron 12:763-773.

Galli C, Meucci O, Scorziello A, Werge TM, Calissano P, Schettini G (1995) Apoptosis in cerebellar granule cells is blocked by high $\mathrm{KCl}$, forskolin, and IGF-1 through distinct mechanisms of action: the involvement of intracellular calcium and RNA synthesis. J Neurosci 15:1172-1179.

Gallo V, Kingsbury A, Balazs R, Jorgenson OS (1987) The role of depolarization in the survival and differentiation of cerebellar granule cells in culture. J Neurosci 7:2203-2213.

Gray-Bablin J, Zalvide J, Pat Fox M, Knickerbocker CJ, DeCaprio JA, Keyomarsi K (1996) Cyclin E, a redundant cyclin in breast cancer. Proc Natl Acad Sci USA 93:15215-15220.

Hatten ME (1985) Neuronal regulation of astroglial morphology and proliferation in vitro. J Cell Biol 100:384-396.

Helin K, Lees JA, Vidal M, Dyson NE, Harlow E, Fattaey A (1992) A cDNA encoding a pRB-binding protein with properties of the transcription factor E2F. Cell 70:337-350.

Kowalik TF, DeGregori J, Schwarz JK, Nevins JR (1995) E2F1 overexpression in quiescent fibroblasts leads to induction of cellular DNA synthesis and apoptosis. J Virol 69:2491-2500.

Kranenburg O, van der Eb AJ, Zantema A (1996) Cyclin D1 is an essential mediator of apoptotic neuronal cell death. EMBO J 15:46-54.

Laemmli UK (1970) Cleavage of structural proteins during the assembly of the head of bacteriophage T4. Nature 227:680.

Losievitz MD, Carlson BA, Kaur G, Sausville EA, Worland PJ (1994) Potent activation of CDC2 kinase activity by the flavonoidL86-8275. Biochem Biophys Res Commun 201:589-595.

Meijer L, Borgne A, Mulner O, Chong JPJ, Blow JJ, Inagaki N, Inagaki M, Delcros J, Moulinox J (1997) Biochemical and cellular effects of roscovitine, a potent and selective inhibitor of the cyclin-dependent kinases cdc2, cdk2 and cdk5. Eur J Biochem 243:527-536.

Miller TM, Johnson EJ (1996) Metabolic and genetic analyses of apoptosis in potassium/serum-deprived rat cerebellar granule cells. J Neurosci 16:7487-7495.

Miller TM, Moulder KL, Knudson KM, Creedon DJ, Deshmukh M, Korsmeyer SJ, Johnson Jr EM (1997) Bax deletion further orders the cell death pathway in cerebellar granule cells and suggests a caspaseindependent pathway to cell death. J Cell Biol 139:205-217.

Mosmann T (1983) Rapid colorimetric assay for cellular growth and survival: application to proliferation and cytotoxicity assays. J Immunol Methods 65:55-63.

Pagano M, Theodoras MA, Tam SW, Draetta GF (1994) Cyclin D1mediated inhibition of repair and replicative DNA synthesis in human fibroblasts. Genes Dev 8:1627-1639.

Park DS, Farinelli SE, Greene LA (1996) Inhibitors of cyclin-dependent kinases promote survival of post-mitotic neuronally differentiated PC12 cells and sympathetic neurons. J Biol Chem 271:8161-8169.

Park DS, Morris EJ, Greene LA, Geller HM (1997a) G1/S cell cycle blockers and inhibitors of cyclin-dependent kinases suppress camptothecin-induced neuronal apoptosis. J Neurosci 17:1256-1270.

Park DS, Levine B, Ferrati G, Greene LA (1997b) Cyclin-dependent kinase inhibitors and dominant-negative cyclin-dependent kinase 4 and 6 promote survival of NGF-deprived sympathetic neurons. J Neurosci 17:8975-8983.

Park DS, Morris EJ, Stefanis L, Troy CM, Shelanski ML, Geller HM, Greene LA (1998a) Multiple pathways of neuronal death induced by DNA-damaging agents, NGF deprivation, and oxidative stress. J Neurosci 18:830-840.

Park DS, Morris EJ, Padmanabhan J, Shelanski ML, Geller HM, Greene LA (1998b) Cyclin-dependent kinases participate in death of neurons evoked by DNA-damaging agents. J Cell Biol 143:457-467.

Pines J (1993) Cyclins and their associated cyclin-dependent kinases in the human cell cycle. Biochem Soc Trans 21:921-925.

Ping Dou Q, An B, Antoku K, Johnson DE (1997) Fas stimulation induces $\mathrm{Rb}$ dephosphorylation and proteolysis that is blocked by inhibitors of the ICE protease family. J Cell Biochem 64:586-594. 
Rakic P (1998) Images in neuroscience. Brain development, VI: radial migration and cortical evolution. Am J Psychiatry 155:1150-1151.

Rukenstein A, Rydel RE, Greene LA (1991) Multiple agents rescue PC12 cells from serum-free cell death by translation- and transcriptionindependent mechanisms. J Neurosci 11:2552-2563.

Schulz JB, Weller M, Klockgether T (1996) Potassium deprivationinduced apoptosis of cerebellar granule neurons: a sequential requirement for new mRNA and protein synthesis, ICE-like protease activity, and reactive oxygen species. J Neurosci 16:4696-4706.

Scovassi AI, Stivala LA, Rossi L, Bianchi L, Prosperi E (1997) Nuclear association of cyclin D1 in human fibroblasts: tight binding to nuclear structures and modulation by protein kinase inhibitors. Exp Cell Res 237:127-134.

Sgambato A, Han EK, Zhang Y, Moon RC, Santella RM, Weinstein IB (1995) Deregulated expression of cyclin D1 and other cell cycle-related genes in carcinogen-induced rat mammary tumors. Carcinogenesis 16:2193-2198.

Shan B, Farmer AA, Lee WH (1996) The molecular basis of E2F-1/DP1-induced S-phase entry and apoptosis. Cell Growth Differ 7:689-697.
Stefanis L, Park DS, Yan CYI, Farinelli SE, Troy CM, Shelanski ML, Greene LA (1996) Induction of CPP32 activity in PC12 cells by withdrawal of trophic support: dissociation from apoptosis. J Biol Chem 271:30663-30671.

Troy CM, Stefanis L, Greene LA, Shelanski ML (1997) Nedd2 is required for apoptosis after trophic support withdrawal, but not superoxide dismutase (SOD1) downregulation, in sympathetic neurons and PC12 cells. J Neurosci 17:1911-1918.

Vesley J, Havlicek L, Strand M, Blow JJ, Donella-Deanna A, Pinna L, Letham DS, Kato J, Detivaud L, Leclerc S, Mieijer L (1994) Inhibition of cyclin dependent kinases by purine analogues. Eur J Biochem 224:771-786.

Williams RW, Herrup K (1988) The control of neuron number. Annu Rev Neurosci 11:423-453.

Wu X, Levine AJ (1994) p53 and E2F-1 cooperate to mediate apoptosis. Proc Natl Acad Sci USA 91:3602-3606.

Yan GM, Ni B, Weller M, Wood KA, Paul SM (1994) Depolarization or glutamate receptor activation blocks apoptotic cell death of cultured cerebellar granule neurons. Brain Res 656:43-51. 